\title{
RESPONSIBLE SOVEREIGN LENDING AND BORROWING
}

\author{
LEE C. BUCHHEIT* \\ G. Mitu GULATI**
}

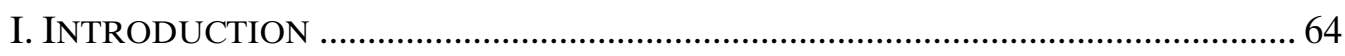

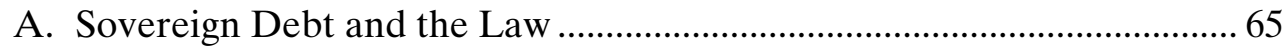

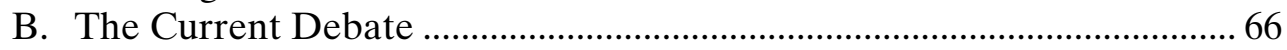

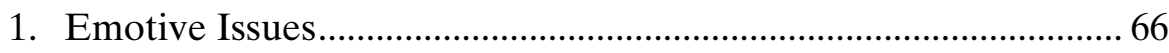

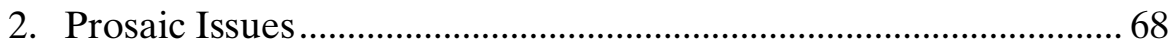

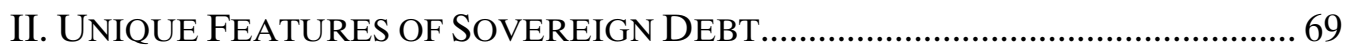

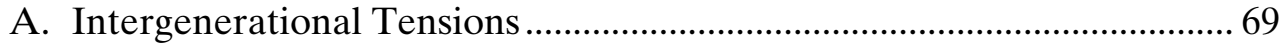

B. Government Officials as Agents ............................................................... 70

C. Mixed Motivations of Certain Lenders ………………................................ 71

D. The Absence of a Formal Bankruptcy Mechanism …………………….... 72

E. The Sovereign Debtor as a Defendant …………......................................... 73

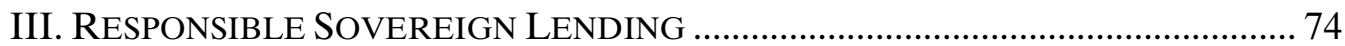

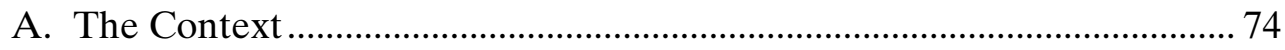

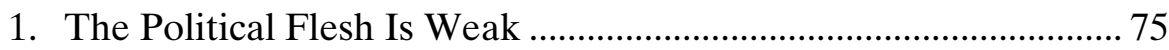

2. The Fiduciary Duty Is High ........................................................... 75

3. Financial Sophistication May Be Absent ........................................ 75

4. The Local Law Will Not Help …………………............................. 75

5. A Lender's Capacity for Rationalization Can Be Fathomless ..... 76

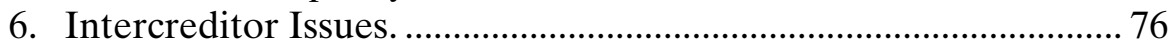

B. The Duties of Responsible Lenders .......................................................... 76

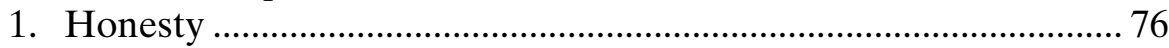

2. Realistic Assessments ........................................................................ 77

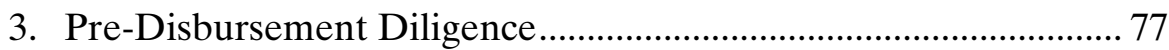

4. Post-Disbursement Diligence ............................................................. 78

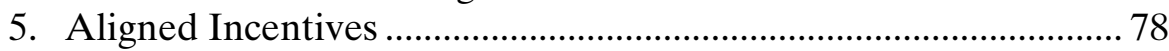

6. Sanctions Regimes ........................................................................... 79

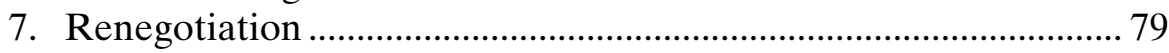

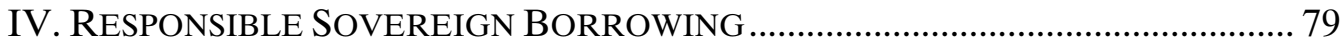

A. The Context ………………………………………................................... 80

Copyright (C) 2010 by Lee C. Buchheit and G. Mitu Gulati.

This article is also available at http://www.law.duke.edu/journals/lcp.

* Partner, Cleary Gottlieb Steen \& Hamilton LLP (New York).

** Professor, Duke University School of Law. The authors wish to thank Seth Reynolds for his research assistance in the preparation of this paper. The views expressed are those of the authors and do not represent the views of the United Nations Conference on Trade and Development. 
1. "A Moment On the Lips, a Lifetime On the Hips" ......................... 80

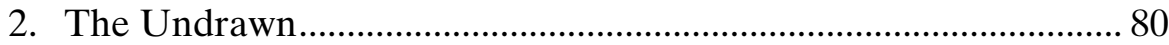

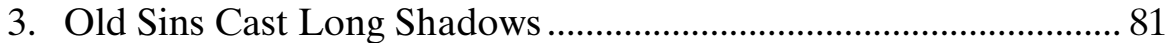

4. Pathological Procrastination ................................................................ 81

B. The Duties of Responsible Borrowers …………....................................... 82

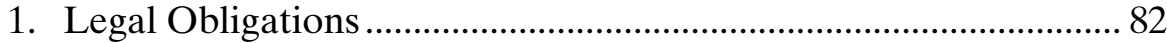

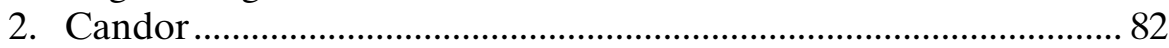

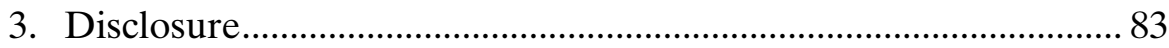

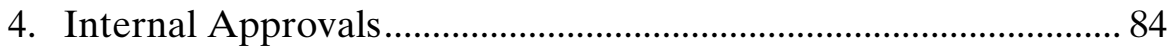

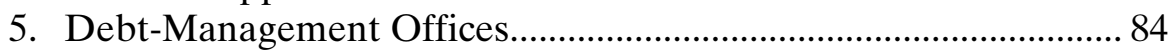

6. Project Due Diligence ………………………….............................. 85

7. Preparation for Debt Management.................................................... 85

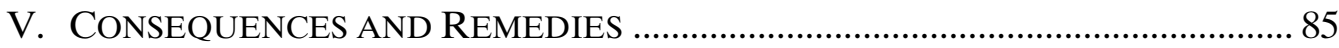

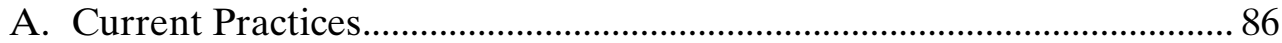

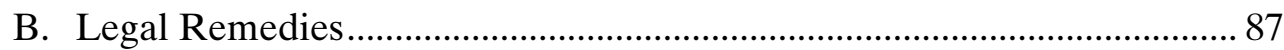

1. The Fiduciary Approach .................................................................. 87

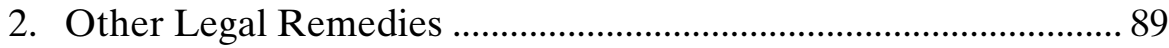

3. Remedies in Debt Renegotiations ..................................................... 90

a. Paris Club ........................................................................... 90

b. Commercial Creditors ............................................................ 91

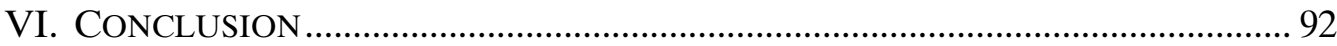

\section{INTRODUCTION}

There are three reasons for attempting to reach a common understanding of the responsibilities of sovereign borrowers and their lenders. First, the flow of capital to sovereign debtors is exceptionally important to the world economy. Industrialized countries rely on it to finance their budget deficits, these days to a breathtaking extent. Developing countries need it to develop. Misbehavior, either by the sovereign debtors or by the creditors, destabilizes this key component of the international financial system, making credit less available and more costly.

Second, sovereign finance is uniquely unforgiving of mistakes. Unlike corporate or personal debtors, sovereigns do not have access to a formal bankruptcy process in which insupportable liabilities can be adjusted according to preestablished rules. From a legal standpoint, sovereign debts are therefore ineradicable absent the consent and cooperation of the creditors. Unfortunately, the process by which that consent and cooperation must be sought—-sovereign debt restructuring-remains unpredictable and disorderly.

Third, the human cost of prodigal sovereign borrowing, reckless sovereign lending or incompetent sovereign debt restructuring is incalculable. Perusing a major international newspaper on any day of any year is all that is required to make good this proposition. A consensus about the responsibilities of sovereign 
borrowers and lenders, together with improvements in the way in which sovereign loans are planned, executed, documented, and, when necessary, restructured, will directly affect the lives of most of the people that live on this planet.

\section{A. Sovereign Debt and the Law}

On its face, the term "sovereign debt" appears to be an oxymoron. A debtat least of the financial kind-suggests an obligation whose performance is legally enforceable against the debtor. The word sovereign, however, connotes an entity that is not subject to external constraints, least of all the tiresome constraint of repaying borrowed money. Yet sovereigns borrow money all of the time, and they pay it back most of the time.

For the last fifty years or so, but only for that long, sovereign debtors borrowing outside of their own territory have been answerable in foreign courts for their performance of those contracts - a doctrine known as the restrictive theory of sovereign immunity. Few believe, however, that sovereigns repay their debts mainly out of a fear of hostile legal action by the creditors. States repay in order to establish their reputation as a trustworthy debtor; in other words, they repay in order to preserve their ability to borrow again on advantageous terms. Sometimes they repay out of a sense of national honor. Often they repay in order to avoid the diplomatic friction that would attend a default on debt obligations owed to sister states or to the nationals of those states. But they do not repay because the law has devised effective means of forcing them to do so. Unsatisfied creditors may now obtain foreign court judgments against defaulting sovereign debtors, and to this extent, one traditional feature of sovereignty has indeed been eroded, but in the end those judgments have proven very difficult to enforce. Why? Because the defendants are sovereign. A state's property located within its own territory is not usually subject to compulsory seizure and a sovereign on the run from its foreign creditors does not like to hold attachable assets abroad. A corporate creditor's last resort, forcing the debtor into bankruptcy and liquidating its assets, is completely lacking in the sovereign setting.

The law of sovereign debt is therefore mostly about what the international community expects sovereign states to do by way of honoring their financial commitments, and only marginally about the rules that national courts apply when a sovereign debtor is sued under a commercial debt instrument. ${ }^{1}$ The expectations of the international community are enforced by diplomatic suasion, backed by the threat of reduced or foreclosed access to further bilateral

1. A good example is Iraq's handling of the roughly $\$ 130$ billion of Saddam-era bilateral and commercial debts that the new Iraqi Government inherited in 2004. Although the statute of limitations for the judicial enforcement of most of these claims had long since expired, Iraq recognized and settled the debts without attempting to filter out those claims that no longer posed a legal threat to the country. See Lee C. Buchheit \& Mitu Gulati, Odious Debts and Nation-Building, 60 ME. L. REV. 477, 484 (discussing the pragmatic approach that was taken to resolving Iraq's outstanding debts in 2005). 
(and sometimes multilateral) funding. The days of enforcing those expectations through the use of military coercion or open intervention in the affairs of a defaulting debtor are happily a hundred years behind us. ${ }^{2}$ Sovereign misbehavior affecting commercial lenders is in theory also punishable by restricted market access, but in this respect, modern sovereign finance is a testament to the Johnsonian triumph of hope over experience. ${ }^{3}$

One objective of attempting to reach a consensus about the principles of responsible sovereign lending and borrowing is to change how this important area of international finance functions in practice. A secondary objective is to position a new government of a state that has previously been victimized by irresponsible sovereign lending/borrowing to seek relief from those debts without sacrificing its (the new government's) reputation in the financial markets or provoking its bilateral creditors to withhold further credit. A tertiary objective is to see whether these principles can be framed in a manner that would allow a judge sitting in a national court to take them into account in a lawsuit with a commercial lender over the judicial enforcement of a sovereign debt instrument.

\section{B. The Current Debate}

Three issues have dominated the public debate about sovereign debt matters in this decade-vulture creditors, odious debts, and the financing of distasteful regimes (these last two are sometimes lumped together). For the reasons discussed below, however, these marquee issues will not dominate this article.

1. Emotive Issues

Vulture creditors. This unflattering term is applied to institutions that purchase defaulted debt obligations of sovereign borrowers in the secondary market, typically for a small fraction of the face value of the instrument, and then threaten or commence a legal action to recover the full amount due. This behavior has incurred much public opprobrium; it often represents a cynical attempt to exploit the willingness of other creditors to grant debt relief to a sovereign borrower. Legislative initiatives designed to curb vulture-creditor activity are being considered on both sides of the Atlantic. ${ }^{4}$

2. For a comparison of the enforcement of sovereign debt in the contemporary era through vulture litigation versus gunboat diplomacy, see generally Faisal Z. Ahmed, Laura Alfaro \& Noel Maurer, Lawsuits and Empire: On the Enforcement of Sovereign Debt in Latin America, 73 LAW \& CONTEMP. PROBS. 39 (Fall 2010).

3. See Ugo Panizza, Frederico Sturzenegger \& Jeromin Zettelmeyer, The Economics and Law of Sovereign Debt and Default, 47 J. ECON. LITERATURE 651, 675-76 (2009).

4. For discussion of the legislation, see Simon Evans, The Vultures that Prey on the Poorest, THE INDEPENDENT (London) (July 26, 2009), http://www.independent.co.uk/news/business/analysis-andfeatures/the-vultures-that-prey-on-the-poorest-1761225.html. In the United States, the legislation is the Stop VULTURE Funds Act, H.R. 6796, 110th Cong. (2008). For a discussion of the legislation in the United Kingdom, see Her MAJESTY's TREASURY, ENSURING EFFECTIVE DEBT RELIEF FOR POOR 
Anecdotal reports suggest that vulture creditors have traditionally relied on one of two stratagems to collect on their claims: blind luck (the good fortune to find an offshore asset of the sovereign defendant that can be attached) or inspired luck (the kind that results from bribing a debtor-government official either to reveal the location of an attachable state asset or deliberately to place such an asset in harm's way, to acknowledge a stale claim and thus restart an expired statute of limitations period, or just to settle the claim for cash). To blind luck and inspired luck, another tactic has recently been added. The vulture may hire investigators to develop a dossier of evidence about the malfeasance or indiscretions of debtor government officials and then agree to suppress these materials in return for a cash settlement of the claim.

The moniker of "vulture" creditor, however, is sometimes handed out too freely. Not every investor who purchases sovereign paper in the secondary market at a discount is a vulture. Indeed, a properly functioning market needs investors who are prepared to stomach greater risk for the greater reward that a discounted purchase of a debt instrument offers the investor. Nor does every creditor who declines to participate in a sovereign debt workout, by that act alone, reveal itself to be a wattle-necked scavenger eyeing its next meal. Sovereigns have occasionally been known to overreach in seeking debt relief from their creditors and no infamy should automatically attach to declining such a request. Malice aforethought is an essential trait of the genuine vulture creditor.

Odious Debts. This term, first coined in 1927, originally referred to obligations incurred by a despotic government for purposes unrelated to the welfare of the state (read, for the personal gain of the despot and his cronies). ${ }^{5}$ A debt could be classified as odious, however, only if the lender knew that the proceeds of the loan were being diverted to purposes that did not benefit the state as a whole. This last criterion severely limited the scope of the original formulation.

The concept of odious sovereign debts has enjoyed a renaissance in the wake of the ouster of Iraq's Saddam Hussein in 2003. ${ }^{6}$ (In the eyes of many, Saddam epitomized the despotic contractor of odious state debts-corrupt, brutal, villainous, and pursued with unseemly eagerness by a pack of prospective lenders.) Odious debts - or its more recent, and allegedly more expansive, formulation "illegitimate debts"-is now viewed by many third world debt activists as a potential legal basis for allowing successor governments to repudiate obligations incurred by corrupt (some would add, incompetent)

COUNTRIES: A CONSULTATION ON LEGISLATION (2009), available at www.hm-treasury.gov.uk/ consult_debt_relief.htm.

5. See Symposium, Odious Debts and State Corruption, 70 LAW \& CONTEMP. Probs. 1 (Summer \& Fall 2007).

6. See id. 
predecessor regimes. ${ }^{7}$ Critics of the odious debt concept argue that the definitional and practical hurdles it faces (for example, what are the necessary and sufficient conditions of a despotic regime?, can a debt be partly odious and partly benign?, can a representative government ever contract an odious debt?, can a despotic government ever contract a benign debt?, who makes all of these decisions?) are insurmountable.

Financing of distasteful regimes. Sometimes folded into the discussion of odious debts and sometimes kept separate is the issue of financing governmental regimes that are for one reason or another viewed as distasteful. The argument here is that any commercial relationship with such a regime tends to give it legitimacy and prolongs its regrettable tenure in office. The loan does not have to be misappropriated in order to offend against this principle; the borrowing government need only be pursuing policies that the condemner finds offensive. The classic example is the financings extended to the apartheid regime in South Africa.

The moral issue in these situations tends to be one of causation. If lender $L$ does business with distasteful regime $D R$, and $D R$ injures (let's say human rights) victim $V$, to what extent is $L$ morally responsible for $V$ 's injuries? Causation (together with intent) can also be the main legal issue if $V$ seeks to hold $L$ answerable in a civil lawsuit for the damages caused by $D R .^{8}$

\section{Prosaic Issues}

Each of these three issues-vulture creditors, odious debts, and financing of distasteful regimes-is highly emotive. Each evokes a sense of moral indignation in certain observers. And each is therefore an appealing candidate in the eyes of some people for remedy through new legal doctrines or machinery, either at the level of national (domestic) law or public international law.

Despite the notoriety associated with these issues, most sovereign debt difficulties are not the product of odious loans, the exactions of vulture

7. The legal issue relates to the question whether odious debts (however this category may be defined) should be recognized as an exception to the normal rule of public international law that all governments "succeed to" the rights and obligations of their predecessors, however different in form and philosophy the two governmental regimes may be. This debate is quite vigorous. The protagonists occasionally-and prematurely-proclaim victory. For example, the following sentence appears in a 2008 report by a committee of the International Law Association entitled "Aspects of the Law of State Succession":

[T] here is a general agreement in practice, confirmed unanimously by international doctrine, that so-called odious debts (that is, debts of the State which do not relate to any interest of the population of the territory or aiming at illegal conduct, like war) are not subject to succession.

Comm. on Aspects of the Law of State Succession, Int'l Law Ass'n, Final Report, 73 INT'L L. Ass'N REP. 250, 330 (2008) (emphasis added).

8. For a very recent U.S. decision in this area, see Presbyterian Church of Sudan v. Talisman Energy, Inc., 582 F.3d 244 (2d Cir. 2009), in which an oil company doing business in the Sudan was held not to be liable under the U.S. Alien Tort Claims Act for aiding and abetting the human-rights violations of the Sudanese regime. 
creditors, or the willingness of some lenders to finance distasteful regimes. Indeed, the cumulative financial effect of these three problems is, in terms of global sovereign finance, probably not material, although it could be significant for an individual country.

The causes and the cures for most sovereign debt problems are far more prosaic than the lurid debate about kleptomaniacal dictators and vulture creditors might suggest. They require an examination into the financing of illconceived or mismanaged projects; the tendency of many governments to use borrowed funds to cover chronic budget deficits because the alternativesraising taxes or cutting expenditures-are politically unpalatable; and similar everyday failings of sovereign debtors. In our view, a discussion of the principles of responsible sovereign lending and borrowing therefore ought to focus mostly on these problems.

In addition, and this extraordinary sentence is being written by two lawyers, it is possible to overemphasize the legal aspects of these issues. Bilateral (government to government) credits almost never find their way into a courtroom and only a trivial percentage of commercial credits wind up there. To an overwhelming extent, sovereign debt problems are negotiated, not litigated. The most useful arguments, including those based on responsible sovereign lending and borrowing practices, are those suitable to be voiced in a negotiating room, not a courtroom.

II

\section{UNIQUE FEATURES OF SOVEREIGN DEBT}

Sovereign debt is unlike every other kind of debt. The differences go a long way to explaining the components of responsible sovereign lending and borrowing.

\section{A. Intergenerational Tensions}

The intergenerational tension in all sovereign borrowing boils down to this: The people who borrow the money are not always the people who must pay it back. In this lies grave risks and heavy responsibilities. Separating the sweetness of borrowing money from the sourness of having to repay it contradicts a basic principle of justice - that the consequences of an act should fall on the actor, not on an innocent third party. Licentiousness, whether of the moral or the financial variety, is at least occasionally held in check by this principle. The habit of sobriety has always found its most effective advocate in the hangover.

Sovereign debt is frequently an exception to this principle. One group of citizens (those who have not yet been born or reached taxpaying age) will eventually be taxed to repay a debt incurred by another group (the incumbent citizens). The temptation this presents for a politician is nearly irresistible. The beneficiaries of today's borrowing vote in the next election; the eventual payors of the debt do not. Thus, the people who would most logically urge restraint and moderation in sovereign borrowing matters remain, at the time of the 
borrowings, mute and disenfranchised as a consequence of the tardiness of their birth.

No one is likely to object if the benefit will itself endure and contribute to the welfare of the future generations that will need to repay the corresponding debt. A bridge or a dam, for example; a road network or public waterworks; or the preservation of the very existence of the state from a military aggressor. The warm part of the debate, uncomfortably warm at the moment in light of the colossal fiscal stimulus policies being implemented by many countries, centers instead on state borrowing to cover large and chronic budget deficits, or to finance items such as discretionary wars or bailouts of failing commercial enterprises.

Now, it might be argued that similar issues are raised whenever a legal fiction like a state or a corporation borrows money. The debt is that of the entity, not its constituent members (citizens or shareholders). By the time a corporate debt falls due in the future, for example, the board of directors, the management, and the stockholders who were present at the time of the incurrence of the debt may have all changed.

This analogy between borrowings by sovereign states and by corporations breaks down in three areas:

First, any new shareholder of the corporation makes a voluntary decision to buy the stock of the company. A bit of diligence by a prospective investor will reveal the company's debt position. With the possible exception of the Dalai Lama, individuals do not elect the location of their birth. By the very act of being born, a person involuntarily assumes a responsibility for repaying the debts of the state in which that event occurs.

Second, shareholders have direct means of monitoring and disciplining corporate managers in matters such as the incurrence of debt. The accountability of government officials to their citizens is in many countries far more attenuated and in some countries utterly non-existent.

Third, the law in many countries imposes duties on corporate managers and directors to avoid self-dealing and to exercise prudent business judgment in carrying out their offices. Under some legal systems, individual officers or directors can be held personally liable for egregious failings of this kind. Government officials do not usually operate under similar legal standards.

\section{B. Government Officials as Agents}

Sovereign borrowing raises fundamental questions of political philosophy. In what relationship do government officials stand vis-à-vis the state and its citizens when the officials enter into contracts that bind the state to future obligations? Are the government officials the agents of, or trustees for, the citizens? And can one be an agent of a principal (a future generation of citizens) that is not yet in existence? To say that governments are the agents of their citizens is of course to express a modern view of the matter. Rameses II 
and Louis XIV would not have recognized this description of their relationship with their subjects.

Much may turn on whether this agency characterization is more than just a metaphor. ${ }^{9}$ An agent owes a fiduciary duty to its principal-the highest form of duty. Any type of self-dealing by the agent is inconsistent with this duty. Moreover, a third party that suborns or colludes in a breach of this duty by the age' nt has forfeited any right to enforce the resulting contract against the faithless agent's principal. So says the ancient law of agency. More importantly, so also says common sense.

Again, an argument could be made that the managers and directors of a corporation stand in a similar relationship to their principal: the company and its shareholders. The difference is that a body of domestic law will usually delineate this relationship in the corporate context and will prescribe the legal consequences for third parties if they knowingly deal with corporate managers who are breaching their duties to the company. ${ }^{10}$

\section{Mixed Motivations of Certain Lenders}

Most people lend money with the objective of making money. The loan itself may be ill-conceived, shallowly researched, and badly structured, but at least the motivation for it is usually straightforward-profit. Not all loans to sovereign borrowers are this simple.

The most common form of sovereign financing that results from an amalgam of lender motivations is a bilateral (government to government) credit granted for the purpose of stimulating exports of capital goods from the creditor country, acquiring geopolitical influence over the debtor, assuring longterm access to raw materials or energy supplies, or inducing the borrower to purchase military hardware from the lender. ${ }^{11}$

A lender's fear of not being able to recover a credit granted to a sovereign or a corporate borrower is an altogether salutary emotion. It engenders caution on the part of the lender. It counsels diligence in investigating the debtor's capacity and willingness to pay. Most importantly, it sits on one of the lender's shoulders and whispers "beware" at the very moment when an imp on the other shoulder is probably muttering the word "bonus."

A bilateral lender with mixed motivations, however, will be at least partially anesthetized to these fears. Such a lender will have accomplished some of its objectives in making the loan (securing geopolitical influence, stimulating exports, or locking in access to natural resources) even if the money is not

9. See Deborah A. DeMott, Agency by Analogy: A Comment on Odious Debt, 70 LAW \& CONTEMP. PROBS. 157 (Fall 2007). level.

10. See discussion infra Part V.B.1 for a proposal that would replicate this feature at the sovereign

11. On the topic of government-to-government debt, see Anna Gelpern, Odious, Not Debt, 70 LAW \& CONTEMP. PROBS. 81 (Summer 2007). 
repaid on time. This can be a uniquely pernicious aspect of lending to sovereigns because it tends to promote over-lending or borrowing.

D. The Absence of a Formal Bankruptcy Mechanism

The possibility of a bankruptcy can profoundly affect the conduct of a corporate-debt workout long before anyone ever begins to lurch toward the bankruptcy courthouse. The rehabilitation of a corporate debtor in bankruptcy is deliberately unpleasant for both the borrower and its creditors. This fact encourages both sides to pursue a consensual workout if one is at all feasible.

Moreover, in the negotiations for an out-of-court settlement, no party ought logically to insist on terms that would be materially worse for the other stakeholders than the terms that those stakeholders would be likely to receive in a formal insolvency proceeding. To do so would virtually guarantee that the disadvantaged party will force the matter into a bankruptcy. Finally, the temptation to sue a borrower is tempered by the realization that such legal actions would automatically be stayed were the debtor, as they say, to seek the protection of the bankruptcy laws.

Sovereign borrowers are not subject to national bankruptcy regimes. ${ }^{12}$ This both helps and hurts the ability of sovereigns to negotiate consensual workouts of their debt problems. On the help side of the ledger is the fact that creditors really have only two options in these affairs-negotiate or litigate (with the latter being subject to significant uncertainties about the ability to enforce resulting court judgments).

On the hurt side, however, are the following:

1. Creditors do not have to worry about the sovereign debtor seeking the protection of the bankruptcy laws if negotiations bog down. Accordingly, sovereigns lack one of the principal tools that corporate debtors use to encourage their creditors to come to the table quickly and with moderate expectations.

2. Sovereigns also lack the ability to force dissident creditors to go along with a settlement that is broadly acceptable to other lenders, something that corporate debtors and majority creditors enjoy in a formal bankruptcy proceeding.

3. Sovereign debtors-unlike corporations or individuals-are completely exposed to creditor lawsuits because they cannot invoke the normal protection against hostile creditor actions that comes with a corporate bankruptcy filing.

12. See generally Sean Hagan, Designing a Legal Framework to Restructure Sovereign Debt, 36 GEO. J. INT'L L. 299 (2005). 


\section{E. The Sovereign Debtor as a Defendant}

As noted above, the laws in many countries relating to the legal immunity of foreign sovereigns began to change in about the middle of the twentieth century. As a result of that change, sovereigns that borrowed money abroad could be sued in foreign courts (without their consent) for the recovery of those credits. $^{13}$

Although these changes in sovereign immunity laws allowed foreign sovereigns to be hauled into foreign courts for unpaid debts, state immunity laws in industrialized countries continue to bestow a high degree of legal protection for foreign state property from compulsory seizure to satisfy a court judgment. Typically, only property that is used for a commercial purpose by the foreign state may be seized and even then certain types of property (such as foreign central bank reserves) often enjoy special immunities. ${ }^{14}$

So a sovereign borrower, in its capacity as a defendant in a foreign court, is in one sense worse off, and in another sense better off, than its corporate debtor counterpart. A corporate debtor can stop all creditor lawsuits by filing for bankruptcy, and the creditors know it. Sovereigns lack this protection. But once a judgment is rendered against a sovereign defendant, the judgment creditor is likely to find it much more difficult to satisfy the judgment through levies against the sovereign's property held abroad. Eight years after Argentina's default on $\$ 100$ billion of bond indebtedness, and literally thousands of lawsuits $^{15}$ (but no recoveries) later, the creditors also know this.

During all the long centuries in which sovereigns accorded each other absolute immunity from the nuisance of having to answer for their contractual undertakings in each other's national courts, the principal remedy for an aggrieved creditor was to seek the diplomatic intervention of its own government with the misbehaving sovereign debtor. The movement toward a more restrictive theory of sovereign immunity in the last half of the twentieth century represented an effort to shift this particular issue from the backs of the diplomats onto the backs of the judges. But this shift was only partially successful, and that too not in large part.

In all that they do outside their own territory, sovereigns are actors on a geopolitical stage. The resolution of their debt problems will inevitably affect neighbors, trading partners, allies, and the financial system generally. No country leaves the conduct of its foreign policy in the hands of its judiciary: an isolated dispute about a contract with a sovereign counterparty, possibly; but the resolution of a national, regional, or global debt crisis, not likely.

13. See W. Mark C. Weidemaier, Contracting for State Intervention: The Origins of Sovereign Debt Arbitration, 73 LAW \& CONTEMP. PROBS. 335, 340-42 (Fall 2010).

14. See Lee C. Buchheit, The Role of the Official Sector in Sovereign Debt Workouts, 6 CHI. J. INT'L L. 333, 338-39 (2005).

15. See, e.g., Argentina Tops Debt Swap Goal but Lawsuits Linger, REUTERS (June 23, 2010), http://www.reuters.com/article/idUSN2320835020100623. 
Sovereign defendants are therefore partly in and partly outside of the courtroom. The policymakers have given the judiciary some role in these matters (presumably on the theory that a sovereign debt contract is, after all, just a contract), while reserving for themselves the ability to ensure that important foreign policy objectives will take precedence when necessary. It is an awkward and confusing position, particularly for the private sector creditors who have been told they must look exclusively to their legal remedies for the recovery of their sovereign credits.

Nowhere is this awkwardness more visible than in the workings of the Paris Club. A debtor country that seeks a restructuring of its debts to Paris Club creditors must invariably accept an undertaking to accord its other creditors a treatment that is "comparable" (in net present value terms) to the one agreed with the Paris Club. ${ }^{16}$ So if a debtor country, after leaving Paris, honors the terms of a loan from a private sector creditor, it will breach this solemn undertaking to the governments of the Paris Club countries. But if that sovereign dishonors the terms of the loan, the judiciaries of those same Paris Club countries will remorselessly hand down judgments against it and assist the creditors in enforcing those judgments against the debtor's property. Consigned to perdition if you do, and consigned to perdition if you don't.

\section{III}

\section{RESPONSIBLE SOVEREIGN LENDING}

\section{A. The Context}

This article will turn first to the "lending" half of the topic: responsible sovereign lending and borrowing. Once upon a time, it would have been thought an act of gross impertinence for a private creditor to demand the disclosure of financial and economic information from a sovereign borrower as a condition to making a loan. ${ }^{17}$ This same view also mandated that private creditors refrain from enquiring too closely into how a sovereign borrower proposed to spend the proceeds of a loan. The borrowers were, after all, sovereign. The suggestion that such a creditor might wish to monitor and even direct the post-disbursement use of proceeds would have been nearly unthinkable. No longer. For the following reasons, the modern view is that sovereign borrowers, at least emerging market sovereign borrowers, should be

16. See LeX RIEFFEL, Restructuring Sovereign DebT: THE CASE FOR AD Hoc MACHINERY 115 (2003); Lee C. Buchheit, The Search for the Intercreditor Party, 8 L. \& BuS. REV. AM. 73, 75-76 (2002).

17. "At the inception of a private loan the prospective creditor has the opportunity of meeting the borrower, of inspecting his business, of judging his ability to pay, of discovering the uses to which the money will be put. In the case of a governmental loan the lender knows all these things only from hearsay, from the unguaranteed prospectus of a banking house which is interested from the point of view of its own profit in floating the loan." MAX WINKLER, FOREIGN BONDS: AN AUTOPSY 18 (1933). 
approached by their lenders with even greater solicitude than the average corporate debtor.

\section{The Political Flesh Is Weak}

Borrowing, if one is fortunate enough to have a willing lender, is easy. With any luck, it can postpone (perhaps until the next government takes office) politically disagreeable steps such as taxing citizens or cutting expenditures. Repaying, and all the taxing and cost-cutting that repayment often entails, is the hard part. Experience teaches that the individuals who daily confront this central temptation of sovereign borrowing-the politicians-can resemble quivering pillars of jelly.

\section{The Fiduciary Duty Is High}

These government officials, however, carry an unusually heavy fiduciary duty when they make decisions about state borrowing. Lenders should remember that the current citizens of the debtor state may never have appointed (in a genuinely democratic sense) the officials who are purporting to bind the state to a debt instrument, and those citizens will probably exercise only limited control over the behavior of the officials once in office. Future citizen taxpayers, of course, are not consulted at all. Under these circumstances, lenders dealing with the agents of the state-the government officials signing the debt instrument-have an independent responsibility to inquire into the background of the loan.

\section{Financial Sophistication May Be Absent}

What politicians lack in fortitude when confronted by fiscal temptation, they rarely make up in financial sophistication. Sometimes the politicians in the borrowing country will be supported by a cadre of competent second-level bureaucrats. Sometimes a well-disposed bilateral or multilateral donor will assist the government in hiring outside experts to design and implement debtmanagement policies. Often, however, there will be a disturbing asymmetry in the financial sophistication of the lender pushing an "innovative financial product" and the government official being pushed.

\section{The Local Law Will Not Help}

Corporate managers are normally subject to some legal standard (even if it is a vague one such as "sound business judgment") when they incur liabilities on behalf of their corporations. Although virtually all countries have laws punishing corruption by government officials, few have tried to legislate a standard of prudence on the part of such officials in carrying out their duties. Lenders should therefore not assume that the government officials with whom they deal are operating in a legal environment that will impose even a minimal judicial review of the wisdom of their borrowing decisions. 


\section{A Lender's Capacity for Rationalization Can Be Fathomless}

Any lender worth its salt can rationalize almost any credit decision at the time it is made. The substance known as the cold gray light of dawn intrudes in this process only when some unimaginative person or group (like the lending institution's credit committee) asks the mundane question, "what ever makes us think that the borrower can repay this loan?" But blend in other motivations for the loan like securing geopolitical influence or promoting exports (for bilateral lenders), or advancing in the quantitative league tables for lead-managed deals (for commercial creditors), and rationalizations may not be exposed as quickly or as ruthlessly.

\section{Intercreditor Issues}

The behavior of one lender to a sovereign borrower affects all other lenders to that borrower. A lender that prudently curtails the size of its own loan because it doubts the borrower's ability to service a heavier debt load may find all the benefit of that restraint undone if the borrower can satisfy its financing desires in the arms of other, less informed or less scrupulous, creditors. ${ }^{18}$ Sovereign finance as it has been conducted for the last thirty years has this prominent feature: lenders lend individually but they restructure their credits collectively. So if a sovereign debtor encounters financial difficulties and cannot continue normal servicing of its bilateral debts, it will be told to seek a restructuring agreement with the Paris Club of creditor countries. In those Paris Club negotiations, the loans of all creditor countries of a particular type will be treated identically. The prudent lenders will thus pay a price for the reckless; the disciplined will bear the cost of their more profligate colleagues. A similar approach has been taken to the restructuring of the commercial debts (loans or bonds) of sovereign borrowers.

B. The Duties of Responsible Lenders

We believe that lenders to sovereign borrowers have the following duties:

\section{Honesty}

Lenders must not suborn or consciously ignore conduct inconsistent with the fiduciary duties of the government officials contracting the debt. The fact that a governing regime in the debtor country may control the law-enforcement and judicial functions in the country, thus making exposure of government corruption unlikely or inconsequential, does not diminish the lender's responsibility. This principle has special relevance in areas such as the financing of the sale of military equipment. The cloak of national security that often envelops such transactions provides an environment that is, to corruption, what a warm, moist Petri dish is to bacteria.

18. For a comparative analysis of the treatment of "abusive" loans in corporate bankruptcy regimes, see Juan Pablo Bohoslavsky, Lending and Sovereign Insolvency: A Fair and Efficient Criterion to Distribute Losses Among Creditors, 2 GOETTINGEN J. INT’L L. 387 (2010). 


\section{Realistic Assessments}

When sovereign credits are motivated exclusively by a commercial objective (the lender's desire to receive back from the borrower debt service payments that exceed the lender's own cost of funding the loan), the lender will have every economic incentive to investigate and realistically assess the borrower's capacity and willingness to repay the debt. If that assessment turns out to be shallow or flawed, the lender stands to lose the one thing it cares most about, its money. This is altogether healthy.

Bilateral (government-to-government) credits that are motivated in part by non-commercial objectives such as promoting the geopolitical influence of the lending country or securing access to supplies of natural resources are a different matter. In these situations, the gravitational pull of these other objectives may induce the lender to perform a gauzier or more wishful assessment of the borrower's repayment capacity as the predicate for a loan that otherwise would not have been granted.

\section{Pre-Disbursement Diligence}

An investigation into the proposed use of the proceeds of a loan should, for the lender, be driven by its own interests. Observers of sovereign lending patterns have long recognized that credits financing visibly beneficial projects in a debtor country stand a better chance of being repaid, particularly if the country undergoes a dramatic change in its governing regime between the date of disbursement and the maturity date. ${ }^{19}$

A lender's diligence investigation prior to disbursement of the proceeds of a borrowing will have two components: commercial and legal. The commercial part will involve an inquiry into the debtor's overall debt servicing capacity as well as the use of the proceeds for the specific loan under consideration. Many lenders also have institutional policies that require them to consider matters such as the environmental impact of a project that is being financed with their money, or the human rights record of the recipient government.

The legal diligence will investigate whether the loan has been appropriately authorized, whether the individuals signing the loan documents have the authority to bind the state, and whether there are any features of the transaction that would cause the borrower to violate its other contractual commitments to third parties. Questioning, sometimes years or decades after the fact, the authority of a government official to bind the state to a particular debt has been a popular method for sovereign borrowers to disavow obligations while attempting to preserve some shred of legal respectability. ${ }^{20}$

19. See Charles Cheney Hyde, The Negotiation of External Loans with Foreign Governments, 16 AM. J. INT'L L. 523, 531 (1922) ("[Lenders] must, at the present day, anticipate dangers in imposing on communities having no voice in negotiation fiscal burdens lacking local approval, unless the benefits of the loan through the expenditure of the proceeds are confined to the territory burdened with service.").

20. See generally Theodor Meron, Repudiation of Ultra Vires State Contracts and the International Responsibility of States, 6 INT'L \& COMP. L. Q. 273 (1957). 
Financings for projects in the debtor country, particularly infrastructure projects, carry a special set of responsibilities for the lender. The modern notion of lender responsibility extends this concept to the reasonably foreseeable consequences of the project being financed. A lender is therefore under a duty to consider factors such as the likely environmental effects of the project, the consequence of the project for indigenous peoples in affected areas, possible damage to archaeological or culture heritage sites, and so forth. ${ }^{21}$

\section{Post-Disbursement Diligence}

Asking what a sovereign borrower intends to do with the proceeds of a loan is pointless if the lender does not secure, for itself, the right to monitor what the borrower actually does with the money after it is disbursed. As a contractual matter, this is usually accomplished through clauses that permit the lender to inspect a financed project, call for certifications from contractors or suppliers to the project, and interview the borrower's auditors.

\section{Aligned Incentives}

The lender is uniquely responsible for ensuring that the incentives of its lending officers are aligned with the longer-term best interests of that institution (which, in this context, means seeing that its loans are repaid). The excessive commercial bank lending of the late 1970s and early 1980s, for example, was fueled in part by the practice of charging up front "loan origination" or "facility" fees calculated on the face amount of the loans. Those fees were taken into income by the lending banks in the year received and directly affected the compensation of the banks' loan origination officers for that year. The bankers thus had a personal financial stake in encouraging a sovereign borrower to sign

21. See, e.g., The "Equator Principles": A Financial Industry Benchmark for DETERMINING, ASSESSING AND MANAGING SOCIAL AND ENVIRONMENTAL RISK IN PROJECT FINANCING 1 (2006), available at http://www.equator-principles.com. The International Finance Corporation has created a list of eight standards that should be applied to any project finance loans. They include (1) Social \& Environmental Assessment \& Management, (2) Labor \& Working Conditions, (3) Pollution Prevention \& Abatement, (4) Community Health, Safety \& Security, (5) Land Acquisition \& Involuntary Resettlement, (6) Biodiversity Conservation \& Sustainable Natural Resource Management, (7) Indigenous Peoples, and (8) Cultural Heritage. INT'L FIN. CORP., INTERNATIONAL FINANCE CORPORATION'S POLICY ON SOCIAL \& ENVIRONMENTAL SUSTAINABILITY 1 (2006), available at http://www.ifc.org/ifcext/sustainability.nsf/AttachmentsByTitle/ pol_SocEnvSustainability2006/\$FILE/SustainabilityPolicy.pdf. For further information, see http:// www.ifc.org/enviro. The Asian Development Bank focuses on projects meant to reduce poverty. When evaluating the merits of a project, it considers whether the project will increase infrastructure, regional integration, education opportunities, sanitation standards, and regional financial markets. It also evaluates the social impact the project could have on gender equality, community "safety nets" for disadvantaged individuals, and involuntary resettlement. See Poverty Reduction Framework: Pillars and Themes of the Enhanced Poverty Reduction Strategy, ASIAN DEV. BANK (2010), http://www.adb.org/ poverty/pillars-themes.asp. The World Bank Inspection Panel follows several guidelines when ensuring sustainability including involuntary resettlement, environmental impact, cultural impact on indigenous people, and their cultural property. For more information, see DANA L. CLARK, CTR. FOR INT'L ENVTl. LAW, A Citizen's GUIDE TO THE WORLD BANK INSPECTION PANEL 1 (2d ed. 1999), available at $\mathrm{http} / / / \mathrm{www}$. ciel.org/Publications/citizensguide.pdf. 
up for the largest possible loan, regardless of the borrower's need or capacity to repay. After the global debt crisis engulfed the banks in the early 1980s, the U.S. Congress put a stop to this practice on the part of U.S. banks by requiring loan origination fees to be taken into income over the life of the loan. ${ }^{22}$

\section{Sanctions Regimes}

If international economic sanctions are imposed on a debtor country, any lending transactions that violate those sanctions should be treated as void, regardless of whether the lender's own jurisdiction has implemented the sanctions into domestic law.

\section{Renegotiation}

Although debt servicing is a high priority for most sovereign borrowers, it is not the only, nor will it necessarily be the highest priority for the use of government resources. There will be occasions when the need to cover those other priorities will leave insufficient funds for normal debt servicing. In these circumstances, a sovereign may need to approach its lenders seeking a renegotiation of the terms of its liabilities. History offers very few examples of countries that have stainless records of debt servicing. ${ }^{23}$

Lenders to corporate and individual borrowers always operate in the shadow of the bankruptcy court, meaning that they recognize the possibility that the terms of their credits may be modified in extreme circumstances. Lenders to sovereign borrowers should similarly recognize that circumstances may arise that will require a restructuring of their credits. The behavior of vulture creditors that consciously attempt to exploit these situations by capitalizing on the willingness of other lenders to reduce or defer their own claims is reprehensible. Just as the prospect of a readjustment of credits in bankruptcy encourages the virtue of prudence in the corporate lender, the possible need to renegotiate sovereign loans should engender equal caution in loans to sovereign borrowers.

\section{IV}

\section{RESPONSIBLE SOVEREIGN BORROWING}

For a sovereign debtor, the goals are to borrow with restraint and prudence and, if gross misfortune prevents the normal servicing of the resulting debts, to restructure them with discipline and competence. Restraint in sovereign borrowing means resisting the temptation to sidestep politically unpopular measures like taxation or curtailment of expenditures through the seemingly painless alternative of borrowing to cover chronic budget deficits. Prudence means ensuring that the proceeds of a loan are spent wisely and for their

22. See International Lending Supervision Act of 1983, 12 U.S.C.A. § 3905 (2006).

23. See CARMEN M. REINHART \& KEnNETH RogofF, This Time Is DifFERENT: EIGHT CENTURIES OF FINANCIAL FOLLY (2009). 
intended purpose. Discipline, in the context of a sovereign debt restructuring, is manifested by seeking debt relief that is proportional to the circumstances in which the debtor country finds itself. Competence in debt restructuring means designing, negotiating, and executing the necessary transaction in a professional manner. The market may forgive the circumstances that forced a sovereign to restructure its debt, but it will long remember and resent any aggravation of creditor losses that can be attributed to the debtor's procrastination and inefficiency in the restructuring process itself.

\section{A. The Context}

A sovereign should bear the following in mind as it approaches its borrowing program.

1. "A Moment On the Lips, a Lifetime On the Hips"

This observation, usually uttered to reinforce the resolve of a wavering dieter, is equally applicable to sovereign debts. Debt stocks tend to grow by a process of relentless accretion. Once money is borrowed, in all likelihood, it will be refinanced with a new borrowing at maturity. And that new borrowing will in turn be refinanced at its maturity, and so forth and endlessly so on. ${ }^{24}$ Sovereign debt stocks may stabilize or diminish when expressed as a percentage of the GDP of the debtor country, but they decline in nominal terms only once in a while, typically in the context of a gut-wrenching debt restructuring. Dieters and government officials should therefore reflect carefully before taking a bite that will result in a more or less permanent bulge on the hips or on the balance sheet.

\section{The Undrawn}

Apologists for energetic sovereign-borrowing programs sometimes rationalize their advice by comparing the size of the country's debt stock to its gross domestic product (GDP)-one of the conventional tools for measuring debt sustainability. A debt to GDP ratio below $60 \%$ is generally thought to be manageable; over $100 \%$ often signals trouble. That said, there are countries, some of them industrialized countries, that run debt to GDP ratios well over $100 \%$ without a breakdown of civil society. The lesson that these apologists

24. Consider this recent cri de coeur by the Prime Minister of a very heavily indebted Caribbean country:

So burdensome is the total debt that for the last 10 years our interest costs and principal repayments have exceeded our total revenues. For this year our interest costs and principal repayments total $\$ 325$ billion [Jamaican dollars] while our total revenue is estimated at $\$ 310$ billion. ...

Jamaica remains perpetually "hooked" on borrowings. Our earnings cannot support our level of indebtedness so we have to keep borrowing to repay what we have borrowed and to do what little we can to provide desperately needed services to the people.

Bruce Golding, Prime Minister of Jam., Address to Parliament on the Supplementary Estimates 2-3 (Sept. 30, 2009), available at http://jis.gov.jm/pdf/PM-SupplementaryEtimates-30092009.pdf. 
wish to draw is that the nominal size of a country's stock of debt (particularly external debt that cannot, as a last resort, be managed by inflation in the debtor country) is not worrisome provided that it is kept within a range proportional to the country's GDP.

This misses one crucial point. The financial strength of a sovereign is measured in its undrawn borrowing capacity; that is, the country's ability to mobilize debt financing to meet future emergencies such as wars, natural disasters, or severe economic collapses. A country that borrows to its saturation point, even if it can service the resulting debt stock in normal times without undue distress, forfeits this strength. Such a country, if confronted by an emergency requiring extraordinary funding, must either print the money (and endure the inevitable inflation) or become a ward of the official sector by tapping the International Financial Institution lenders of last resort.

\section{Old Sins Cast Long Shadows}

A sovereign debt stock will form part of the inheritance of the next generation, but so also will a country's record of sovereign debt management. When a politician pursues short-term political popularity by dishonoring debts that are well within the capacity of the country to pay, a different form of tax is levied on successor generations. In some amount, and for some indeterminate period of time, the country in question will be denied access to capital markets or will have to pay a basis point premium for whatever money it can borrow, in order to compensate for the market's memory of such populist grandstanding. ${ }^{25}$ The only saving grace is that no one at the time will be able to quantify the precise amount of this tax. By the same token, a sovereign debtor that garners a reputation for behaving responsibly and competently in the face of financial difficulties will pass the benefit of that reputation on to succeeding generations. ${ }^{26}$

\section{Pathological Procrastination}

In the popular imagination, the principal risk of sovereign lending is the casual default; the politician who decides that, all things considered, it would be more convenient to divert the resources required to service debts inherited from prior administrations toward spending on social projects that will ensure the popularity of the current regime. This is not in fact the principal risk. Although instances of casual sovereign defaults have occurred, they are surprisingly infrequent.

25. "[W]hen the credit of a country is in any degree questionable," U.S. Treasury Secretary Alexander Hamilton warned the first Congress of the United States, "it never fails to give an extravagant premium, in one shape or another, upon all the loans it has occasion to make." Alexander Hamilton, U.S. Sec'y of the Treasury, First Report on the Public Credit (Jan. 14, 1790), in 2 THE WORKS OF ALEXANDER HAMILTON 47, 48 (Henry Cabot Lodge ed. 1885).

26. See Felix Salmon, Uruguay's Elegant Transformation, EUROMONEY (Feb. 2004), at 1, available at ProQuest Doc. ID 582367671. 
By far the greater risk is pathological procrastination by the debtor in the face of an obviously untenable financial situation. Debt crises are almost always preceded or accompanied by political, banking, or social crises. No rightthinking politician wants to tread that path short of absolute, incontrovertible, and inescapable necessity. So remedial measures are often denied and delayed while the country pursues frantic (and often ruinously expensive) emergency financings. When these run out, credits begin to fall into default, lawsuits and attachments are commenced, monetary reserves run dry, and the eventual recovery process is rendered much more difficult.

The International Monetary Fund (IMF) is morbidly sensitive to the allegation that it "told a country to default." Accordingly, while the Fund staff can refuse to recommend an IMF program for a country that remains in denial about the extent of its debt problems, the staff will not prescribe a debt rearrangement unless the country signals its willingness to entertain such a measure.

\section{B. The Duties of Responsible Borrowers}

We believe that sovereign borrowers have the following duties:

\section{Legal Obligations}

Borrowing money connotes a legal obligation to repay the money. The only possible baseline assumption for an efficient financial market is that debts will be honored according to their terms unless there is a good reason why they cannot or should not be. If this assumption were to be eroded in any significant degree, the flow of capital to sovereign debtors would be painfully reduced. As noted above, circumstances will sometimes arise that will make it unreasonably burdensome for a sovereign to continue normal debt servicing and everyone, borrower and lender, should recognize this, but casual or politically-motivated dishonorings of sovereign debt obligations harm both the debtor country and the global system on which so many other countries rely for necessary finance.

\section{Candor}

The credit of the sovereign is either engaged for the repayment of a debt or it is not. So-called "implicit" sovereign guarantees of the debts of political subdivisions, state-sponsored entities, or strategically important private enterprises obscure a country's true debt position, confound efforts to assess debt servicing capacity, distort the pricing of sovereign credits, and plant the seeds of outrage on the part of the putative beneficiaries of such implicit guarantees if and when the guarantees are not honored. The motivation for resorting to this practice is obvious: it allows the privileged obligor to borrow at a lower interest rate than its own orphan credit rating could command, while permitting the sovereign to keep the backstopped liabilities off of the state's balance sheet (right up until the moment that the "implicit" guarantee is called, that is). Citizens, taxpayers, and creditors of the sovereign are thus beguiled into believing that the country's finances are in better shape than they really 
are.

The popularity of a similar technique badly hurt some private financial institutions in the present financial crisis. Assets and liabilities were moved to "structured investment vehicles" (SIVs) and kept off the books of the financial institutions that sponsored the SIVs. When the crisis struck, however, and the investors in the SIVs were facing losses, some of the sponsoring financial institutions suddenly realized that they had "reputational capital" at stake in the whole affair. The SIVs were then collapsed and their liabilities disastrously taken back onto the balance sheets of their sponsors.

3. Disclosure

For every dollar over-borrowed, there are one hundred cents over-lent. Fair enough. But criticizing lenders for making loans that are beyond the reasonable capacity of a sovereign borrower to repay is a little harsh if the sovereign has failed to make available to those lenders (or to the market generally) the information about its financial condition and prospects that would allow the lenders to reach an informed judgment about the country's debt servicing capacity.

This is not a new concern. For as long as sovereigns have been borrowing, lenders have been complaining about the paucity of information upon which to form an enlightened credit decision. "There is no question but that the major cause of default is the lending of money to unstable, undependable borrowers," wrote Max Winkler in 1933, "and that original deception of the lender in regard to the status of the borrower goes directly to the hub of the whole dilemma."27

The traditional bashfulness of sovereign debtors to disclose economic and financial information about themselves probably has a political explanation. An incumbent administration's stewardship of the economy can be assessed and, if you belong to a political group other than the incumbent, criticized, if current information of this type is in the public domain. Central bank governors also worry that allowing the market to monitor on a current basis the country's international monetary reserve levels might precipitate capital flight if sharp and unexpected drops in reserves occur.

In this area at least, great strides have been made in recent years. Starting in 1985 , commercial bank lenders to the more than twenty countries that were forced to restructure their external debt in that decade began to require their sovereign borrowers to provide information that was comparable, in both nature and quantity, to the information countries furnish to the International Monetary Fund. In 1996, the IMF sponsored the Special Data Dissemination Standard (SDDS), a monitored standard designed to assist countries that have or may wish to seek access to international capital markets in the dissemination of economic and financial data to the public. Sixty-four countries have to date

27. WINKLER, supra note 17 , at 58. 
agreed to participate in the SDDS. ${ }^{28}$ Finally, the general shift from bank loans to tradable bonds as the principal medium for private capital flows to emerging market countries has entailed the preparation of disclosure-rich prospectuses and information memoranda.

\section{Internal Approvals}

As a general rule, the more organs of government that must be consulted in state borrowing operations, the safer things will be. The law of most countries requires legislative approval, sometimes given in advance in the form of "debt ceilings," for government borrowings. Typically the attorney general or other chief legal officer of the government will be asked to pass on the legality of any borrowing transaction. A government auditing department may be charged with examining the books and records of the transactions. ${ }^{29}$ This helps in two ways. First, in a democracy, the legislature-representing the ultimate payors of the debt, the taxpayers - are probably best positioned to make the cost/benefit assessment that should precede any responsible sovereign borrowing. Second, the more individuals who must approve a lending transaction, the less likely that the loan will be corruptly induced or executed. It is not a question of superior virtue on the part of these individuals; rather it is the very practical protection that results from dividing a finite amount of potential graft into a larger number of potentially upturned palms.

\section{Debt-Management Offices}

Some countries maintain separate debt-management offices (DMOs), usually lodged in the ministry of finance or the central bank. These entities can be enormously helpful in keeping track of borrowing both by the state itself and agencies and instrumentalities of the state. The DMOs can also offer professional advice and assistance to the government and the public sector obligors in the negotiation of sovereign borrowings, both on legal as well as financial issues.

Such centralized supervision of borrowings can help avoid a major risk for emerging market countries - the danger that one public sector entity will agree, in the context of negotiating a specific transaction, to a financial term (for example, an interest rate) or a contractual provision that future lenders then treat as the standard for all loans to public sector entities in that country. ${ }^{30}$

28. See generally William E. AlEXANDER ET AL., THE IMF's DATA DissEMINATION STANDARD AFTER 10 YEARS (2008).

29. Such audits, if they are to serve any useful purpose, should be conducted within a reasonable period after the closing of the transaction. So-called "audits" of transactions and events that occurred decades in the past, by their very nature, cannot accurately reconstruct what happened, much less why it happened.

30. See LeE C. BuchHeit, The Role of THE LAWyer In EXTERnAl DebT MANAGEMENT 9 (1995) (UNITAR Doc. No 5), available at http://www.unitar.org/pft/sites/default/files/DocSeries5.pdf. 


\section{Project Due Diligence}

The due-diligence investigations that prudent leaders undertake before disbursing funds for a specific project and the post-disbursement monitoring of the use of proceeds should have their counterparts on the borrower's side of a transaction. "Buyer's remorse" is not a recognized basis for avoiding the obligation to repay a loan incurred to finance an ill-conceived or ill-executed project. There was a time when some borrowing countries made a practice of seeking funding from the multilateral development banks for what might charitably be called creative projects, principally as a way of accessing the Multilateral Development Bank's foreign currency disbursements.

\section{Preparation for Debt Management}

Sovereign debt restructurers, like certain types of bacteria, exist on this planet because things do not always work as they are supposed to. Recognizing that something could go wrong is not the same as encouraging it to happen, any more than the act of insuring one's house signals a drift toward arsonist tendencies. As it applies to sovereign debt, this means that the instruments evidencing a sovereign's borrowings (at least its external borrowings) should contain provisions that will facilitate discussions with, and collective decisions by, the creditors should a renegotiation of the debts ever be required.

Here too, considerable progress has been made in recent years. After a titanic struggle, collective action clauses (CACs, that is, contractual provisions permitting a change to the payment terms of a debt instrument with the consent of a supermajority of holders) were successfully introduced into sovereign bonds governed by New York law in 2003. Since then, they have become a standard feature of sovereign bonds issued in the New York market (they already were standard in London). ${ }^{31}$ The initial reluctance of sovereign issuers to incorporate CACs into their New York-law governed bonds centered on a concern about "signaling"; would prospective buyers of the bond interpret the presence of a clause designed to facilitate a restructuring of the instrument as an indication that the issuer was soft on default. In the end, these fears proved to be unfounded.

\section{$\mathrm{V}$ \\ CONSEOUENCES AND REMEDIES}

What sanction should be imposed on a creditor that fails to lend responsibly or on a debtor that fails to borrow responsibly? One is tempted to say that natural justice and implacable market forces will in due course administer an appropriate penalty. The reckless lender will face a higher incidence of

31. A notable exception is Jamaica, a country that has a debt to GDP ratio approaching $140 \%$ and that spends nearly $60 \%$ of its total government revenues on debt service. Notwithstanding the fragility inherent in such a situation, Jamaica has elected not to include collective action clauses in its external bonds. See generally Bear, Stearns \& Co. Inc., Prospectus Supplement: Government of Jamaica: 9\% Notes due 2015 (2005). 
defaulted loans, more (and more severe) debt restructurings and an increasing dissatisfaction on the part of its shareholders. The profligate sovereign borrower will pay a price in terms of reduced market access, higher interest rates, and tighter financial covenants.

This is not an entirely satisfactory response. The reprimand of the market may be sure, but it is not always swift. Natural justice can take an uncomfortably long time to achieve its righteous balance. The individuals on both sides of a sovereign lending transaction, however, are likely to have shorter time horizons, often bounded on the borrower's side by a political calendar and, on the lender's side, by the approaching end of a financial reporting period or an impending conversation about bonus compensation. Thus, the fear of a retributive natural justice operating over a longer term may not be enough to promote short-term prudence on the part of either the borrower or the lender.

One problem with fashioning a remedy for many types of irresponsible behavior in this area is that a conventional legal remedy is destined to be insufficient. Despite the inroads of the restrictive theory of sovereign immunity and the effort to force sovereign borrowers to be accountable for their debt contracts in the same way as private actors, the norms of sovereign lending are largely extra-legal. Breach those norms and the sanction will be imposed by investors, debt traders, and diplomats-not judges. In order to make a practical difference, principles of responsible sovereign lending and borrowing must therefore influence how these credits are treated in an out-of-court renegotiation or restructuring, whether of the bilateral or the commercial variety. A related objective is to ensure that the rating agencies and the market will fairly apportion the blame for a sovereign debt problem when both the sovereign debtor and some of its lenders are contributing agents. This may affect the market's memory of the incident and the extent to which the sovereign will have to pay a price, measured in basis points, for its tarnished debt record.

\section{A. Current Practices}

All sovereign debt crises share one thing in common, they are crises. Once a debt rearrangement becomes unavoidable, the priority of the debtor government usually shifts to resolving the problem as quickly as possible. (Argentina, which defaulted on its bonds in 2001 but did not make an offer to restructure those instruments until 2005, is a prominent exception. $)^{32}$ Faced with hundreds, thousands, or tens of thousands of individual creditor claims that need to be restructured, no one will have the time, the patience, or the resources to examine the circumstances giving rise to each of those debts and to make fine judgments about the extent, if any, of a lender's contributory

32. See Arturo C. Porzecanski, From Rogue Creditors to Rogue Debtors: Implications of Argentina's Default, 6 CHI. J. INT'L L. 311 (2005). 
negligence. The sheer complexity of a large sovereign debt restructuring forces the organizers to divide the debts into a handful of categories (for example, multilateral, bilateral, trade credits, unsecured (non-trade related) commercial debts, interbank lines, and a few others), and to accord even-handed treatment to the creditors within each category. The creditor that performed an agonizing due diligence prior to lending its money at an interest rate of, say $5 \%$, will probably receive the same treatment in the eventual restructuring as the lender who allowed the prospect of extracting a $17 \%$ coupon to supplant any analysis of the borrower's ability to repay the loan.

In short, sovereign debt restructuring, as it has been practiced for the last several decades, dips a very broad brush into a bucket of whitewash before liberally slapping it over a country's debt stock, concealing both the sins of the wicked, and the merits of the virtuous, lenders. It thus neutralizes a central motivation for any lender to pursue responsible sovereign lending practicesnamely, the fear of being disadvantaged in any workout of the country's debts that may become necessary down the road.

\section{B. Legal Remedies}

There does not appear to be any single method by which the principles of responsible sovereign lending and borrowing can be universally promoted, but certain types of irresponsible conduct may be remediable at law.

\section{The Fiduciary Approach}

One idea that is being extensively discussed in the context of the odious debt debate advocates a system in which disfavored regimes are publicly identified in advance by some authoritative body (it has therefore been dubbed the ex ante approach), and any loans to those countries that occur while the regime remains on this list will be voidable if the regime is ousted from power. ${ }^{33}$ The obvious questions are who makes the determination of which regimes fall into this disfavored category, according to what criteria, and with what consequences. We have reservations about whether such a system could work if the criteria for identifying the targeted regimes were cast too broadly (and involved, for example, asking some political body to render public assessments of the behavior of its members in areas such as human rights, religious tolerance, child labor, freedom of the press, the treatment of women, and so forth). Moreover, there could be perverse and unintended consequences. For so long as the abusive regime remains in power, lenders will presumably extract a heavy price in terms of risk premiums to compensate for the possibility that their loans may one day become irrecoverable. That price is ultimately paid by the very people (the citizens of the debtor country) who are expected to benefit from this approach. Also, in extreme cases, the prospect of facing a total loss of their credits might induce lenders to prop up a regime that might otherwise fall.

33. See Seema Jayachandran \& Michael Kremer, Odious Debt, 96 Am. Econ. ReV. 82 (2006). 
In at least one area, however, we believe that the ex ante approach might be workable. Individual incidents of corrupt behavior by government officials may be difficult to prove, but widespread corruption in a country usually attracts notoriety. It becomes the subject of innumerable anecdotes told by business people in airport lounges; it may be publicized by nongovernmental organizations (NGOs) on websites and described in literature of the "doing business in Ruritania" variety. The censured conduct in this case does not call for a judgment about the politics or the policies of the misbehaving regime; it rather goes to the validity of the contract itself. Are the individuals purporting to engage the credit of that state doing so in a manner consistent with their fiduciary duties to the state and its citizens?

The argument for a limited ex ante approach focused solely on fiduciary issues would proceed as follows:

1. All governments-even those not democratically elected-stand in a fiduciary relationship to their states and its citizens. This is the jurisprudential heart of the argument and all else flows from it. We believe that it is a proposition that would, in the twenty-first century, be accepted by most countries and commentators.

2. When government officials act in contravention of these fiduciary duties, they are acting outside the scope of their lawful authority, whatever local (municipal) law may say about their putative authority.

3. Government officials acting outside the scope of their lawful authority lack the legal capacity to bind the state to a contract. If a counterparty enters into such a contract knowing that the government officials signing the instrument lack the legal capacity to bind the state, that contract is at best personal to the government officials concerned and cannot be enforced against the state.

The crucial question is who is to make the determination that a particular governmental regime is habitually acting in a manner inconsistent with its fiduciary duties to the state and its citizens? This determination cannot be left to the judgment of interested parties such as successor governmental regimes that may have a financial incentive to repudiate contracts signed by their predecessors. The strong presumption of international law must be that recognized governments have the legal authority to bind their states in matters of international relations and commercial affairs. Any judgment that a particular governmental regime is no longer entitled to that presumption of legal capacity should therefore be made by an authoritative, disinterested body.

Contractual counterparties should be entitled to rely on the presumption of a government's capacity to bind the state unless put on notice to the contrary by an authoritative source. Under the ex ante approach, any contracts entered into after such a determination has been made public would be voidable by a successor government or perhaps even be open to challenge by a group of 
citizens of the state concerned in circumstances where the offending regime remains in power and attempts to perform the contract.

Why, it might be asked, not just allow a successor government to adduce evidence of a breach of fiduciary duties by their predecessors if ever the creditor seeks to enforce the debt instrument at law-the ex post approach to the problem? We believe there are four answers.

1. Advance identification of offending regimes allows the successor government to show that the lender assumed the risk of the transaction from the outset.

2. Proving what a lender knew or did not know about a governmental regime years previously can be exceptionally difficult. Advance publication of a list of offending regimes avoids this problem entirely.

3. All ex post remedies must confront the possibility, indeed the likelihood, that the debt instrument will have been sold in the secondary market before it becomes the subject of a legal action. Under normal rules governing negotiable instruments, an innocent purchaser of such an instrument takes it free of any defenses that the obligor may have had against the original creditor. The ex ante approach deals with this problem by putting a remote purchaser on notice of the existence of such a potential defense.

4. An ex post approach implies a case-by-case determination by municipal courts. So there is always the chance of inconsistent outcomes depending on where a case is litigated. In contrast, an ex ante determination contemplates that some authoritative body has reached a consensus judgment on the crucial issue of compliance with fiduciary responsibilities before any lawsuits have been filed.

\section{Other Legal Remedies}

Other types of extremely irresponsible lending behavior may have a legal remedy under existing doctrines of municipal law. Examples are sovereign loans that are tainted by corruption at the time of their incurrence or that violate international sanctions regimes. As to the former, the sovereign debtor should have a defense against legal enforcement of the loan under the laws of most jurisdictions. ${ }^{34}$ The problems here are likely to involve proving the lender's complicity in the corruption, particularly if the loan was contracted in the distant past, and finding an appropriate remedy in situations where the debt instrument was sold in the market to an innocent third party who was not aware of its corrupt provenance.

34. See Lee C. Buchheit, G. Mitu Gulati \& Robert B. Thompson, The Dilemma of Odious Debts, 56 DUKE L.J. 1201, 1232-35 (2007). 
With respect to sanctions-busting loans, a public policy defense should be available to the sovereign debtor, at least if it is sued in a jurisdiction that itself implemented the sanctions into its domestic law.

\section{Remedies in Debt Renegotiations}

The tougher cases are those where there has been no outright violation of law in the transaction, but the lender has behaved in a manner that ought, as a matter of fairness, to affect how its loans are treated in any subsequent debt restructuring. Aside from a sovereign's understandable desire to move a restructuring along quickly, all sovereign debt restructurings compel the debtor to secure creditor cooperation without resort to anything like the mandatory "cram down" procedures that are available in corporate bankruptcies. The creditors must therefore be persuaded, cajoled, or prodded into participating; they cannot be commanded to do so. Any proposal to encourage responsible sovereign lending by penalizing (in a debt restructuring) irresponsible lending therefore risks alienating the affections of the allegedly irresponsible creditor. That in turn diminishes the chances of securing the cooperation of that creditor in the restructuring program. We have no ready answer to this very practical dilemma, but offer these thoughts:

\section{a. Paris Club}

This risk is less of a problem in Paris Club restructurings because the Club traditionally reaches its decisions by consensus. ${ }^{35}$ Thus, if the members of the Paris Club were to agree that certain types of lending to a debtor country involved an element of what might be called contributory responsibility on the part of the lender, it is within the power of the Club to discriminate against those credits in an eventual restructuring.

We would not expect this idea to be popular with all Club members. For obvious reasons, the Paris Club creditors have long been suspicious of embracing principles-particularly vague principles like odious debt-that could operate to invalidate a significant portion of their claims against debtor countries. Debts arising as a result of the financing of weapons sales, for example, might appear to be a good candidate for discriminatory treatment in a restructuring, but the Paris Club members who dominate the armaments industry might not see it that way.

Even in situations where a particularly distasteful regime has been removed from power in the debtor country, the Club does not relish hearing that it should consider giving deeper debt relief in atonement for the willingness of Club members to lend to the ancien régime. When the new government of Iraq approached the Paris Club in 2004 for a restructuring of the gargantuan debts

35. Debt Sustainability Analysis: An E-Learning Training Course: Module 3, I.(i) Official Bilateral Debt: The Paris Club, UNITED NATIONS CONFERENCE ON TRADE AND DEVELOPMENT GLOBALIZATION AND DEVELOPMENT STRATEGIES, http://vi.unctad.org/debt/debt/m3/Section\%20I (i).htm (last visited Oct. 4, 2010). 
accumulated by the Saddam regime, for example, the Iraqis carefully avoided basing their case for highly concessional debt relief on the fact that the Club members had been prepared to do business with a regime that was (by then) universally reviled. That said, the issue was undoubtedly a contributing factor in the Iraqis' ability to secure a very favorable Paris Club deal. ${ }^{36}$

There is at least one precedent in Club practice for special treatment along these lines. In a September 17, 1997, press release ${ }^{37}$ announcing that the Russian Federation had become a member of the Paris Club, the Paris Club Secretariat said that Russian claims against debtor countries coming before the Club that had been inherited from the former Soviet Union would be "reduced by an upfront discount" (before applying any Paris Club debt relief) in order to make them "comparable with other Paris Club members' claims." The reason for this across-the-board haircutting of Soviet era claims was not disclosed.

\section{b. Commercial Creditors}

If a lender to a corporate borrower engages in some form of wrongful behavior that injures its fellow lenders, it should be prepared to be penalized for that conduct in the borrower's bankruptcy proceeding. In U.S. law, such a lender's claim may be "equitably subordinated" to those of other creditors. That decision, of course, rests in the discretion of the bankruptcy judge.

In sovereign debt workouts, there is no neutral adjudicator like a bankruptcy judge with the power to make these decisions. A sovereign debtor's options are therefore either to swallow hard and give an irresponsible lender the same treatment as all the other creditors, or to discriminate in some way against the malefactor in the financial terms of the restructuring. The latter choice runs the risk that the disadvantaged creditor may refuse the deal, in which case the sovereign can only hope that the lender's misbehavior at the time the loan was extended will provide a legal defense if and when an enforcement action begins.

Sovereign debt restructurings sometimes equalize the positions of creditors in a way that can deprive a lender of the fruits of a particularly hard bargain that it had imposed on the debtor. For example, Iraq's restructuring in 20052006 of Saddam era commercial claims — claims that had been in default for the

36. Iraq's then Minister of Finance (subsequently Vice President), Adil Abdul Mahdi, made only an oblique reference to this consideration in his opening remarks to the Paris Club delivered on November 17, 2004:

We all know the motivations that led Saddam to accumulate this debt, and we all know how he spent the money. I am not going to retell that story here or draw any conclusions from it. But everyone should recognize that unlike countries whose borrowings finance growth and development, Saddam borrowed much of this money to make war upon his neighbors, to threaten the international community and to oppress his own people.

Adil Abdul Mahdi, Minister of Fin., Opening Remarks at the Meeting of the Paris Club (Nov. 21, 2004) (on file with Law and Contemporary Problems).

37. Press Release, Paris Club (Sept. 17, 1997) (on file with authors); see also U.N. SecretaryGeneral, Debt Situation of the Developing Countries as of Mid-1998: Rep. of the Secretary-General, II 26, U.N. Doc. A/53/373 (Sept. 11, 1998), available at http://www.unctad.org/en/docs/a53d373.pdf. 
fifteen years prior to the restructuring-employed a uniform accrual rate for purposes of calculating past due interest over that extended period. This neutralized the advantage that those lenders holding debt instruments with very high penalty interest rates would have realized had the calculation of past due interest been undertaken strictly in accordance with the terms of each instrument.

VI

\section{CONCLUSION}

There have been times over the last thirty years when sovereign debt issues have been the stuff of front page newspaper headlines. It looks almost certain that they will be again. The extraordinary increases in the public sector debt stocks of many countries resulting from the need to finance economic stimulus packages over the last eighteen months will inevitably force the policymakers in those countries to make some difficult choices down the road. Whether these debt burdens can be managed without undue violence to principles of intergenerational equity remains to be seen.

That will be the main challenge for the industrialized countries. For the developing countries, particularly the heavily indebted poor countries (HIPC), an important debt management challenge may come from a different direction. How will these countries respond to the new class of generous and highly motivated bilateral lenders? Will HIPC countries be able to borrow from this new group of eager lenders in a disciplined way? And equally important, how will those new bilaterals react when the time comes, as it surely will, to restructure some of these credits?

The world has seen enough sovereign borrowing and enough sovereign debt restructuring to know the difference between efficient and mangled operations. The benefits (when it is done right) or the costs (when done some other way) to the sovereign debtor, its citizens, and its creditors are graphically illustrated by numerous examples. ${ }^{38}$ In short, we do not lack the intellectual motivation to pursue responsible sovereign lending and borrowing practices. As always, it will come down to a matter of political will and balancing long-term benefits against short-term temptations.

38. See Federico SturZenegger \& Jeromin Zettelmeyer, Debt DeFAults AND Lessons FROM A DECADE OF CRISES (2006). 